\title{
Biosemiotic medicine: From an effect-based medicine to a process-based medicine
}

\author{
Carlos G. Musso, M.D., Ph.D. ${ }^{a, b}$
}

\begin{abstract}
Contemporary medicine is characterized by an increasing subspecialization and the acquisition of a greater knowledge about the interaction among the different body structures (biosemiotics), both in health and disease. This article proposes a new conceptualization of the body based on considering it as a biological space (cells, tissues, and organs) and a biosemiotic space (exchange of signs among them). Its development would lead to a new subspecialty focused on the study and interference of disease biosemiotics (biosemiotic medicine), which would trigger a processbased medicine centered on early diagnosis and management of disease.

Key words: medicine, biosemiotics, diagnosis, therapy.
\end{abstract}

http:/ / dx.doi.org/10.5546/ aap.2020.eng.e449

To cite: Musso CG. Biosemiotic medicine: From an effect-based medicine to a process-based medicine. Arch Argent Pediatr 2020;118(5):e449-e453.

\section{INTRODUCTION}

Contemporary medicine is characterized by a steep rise in scientific knowledge, a phenomenon that has inexorably incited two highly significant situations. On the one side, an increasing trend towards subspecialization, which is a direct result of human inability to individually encompass the entirety of the vast scientific knowledge produced at present in a timely manner that would allow for its effective implementation in health care practice. On the other side, the progressive acquisition of an increasing knowledge about the close dialogic interaction (semiosis) that takes place among the different body cells, tissues, and organs, both in health (physiology-salutogenesis) and disease (pathophysiologypathogenesis).
Such knowledge evidences the existence of a large and intricate interconnected network among the different body structures, which accounts for a sort of "communication channel" among its elements, a true "dialogic or semiotic space" that is conceptually abstract but experientially real, through which normal and pathological intra- and interparenchymal dialogs (sign exchange) occur. Such dialogs determine a balanced functioning of organ systems or the onset and establishment of disease, respectively. The investigation and analysis of such phenomenon is the subject of a relative new discipline: biosemiotics, which deals with the study of the natural world's language. ${ }^{1}$

The objective of this article is to propose a new form of conceptualization of how live beings in general, and human beings in particular, are formed based on biosemiotics' principles and also to describe the potential benefits that this new perspective may bring to health care.

\section{Biosemiotics: Nature's discourse}

In the early $20^{\text {th }}$ century, biologist Jakob von Uexküll became the first person to propose that every organism establishes a vital information exchange with its environment (umwelt), which leads to an external semiosis or information semiosis process that von Uexküll called exosemiosis. ${ }^{1,2}$ Later, his son, medical doctor Thure von Uexküll, together with medical doctors Werner Geigges and Jörg Herrmann, extended this concept to the inner body (symptomatization semiosis), where information (sign) exchange takes place inside and among each of the different biological complexity levels 
of the body: cells, tissues, organs, and organ systems.

This process, which Thure von Uexküll et al. called endosemiosis, has vast semiotic proportions if we consider that the human body alone is made up of approximately 25 trillion cells, which is equivalent to more than 2000 times the world population. Of course, both semiotic processes (exosemiosis and endosemiosis) are delicately coordinated, thus leading to a bidirectional information flow between the body and its environment that Jakob von Uexküll called feedback loop. Finally, Thure von Uexküll, together with linguist Thomas Sebeok and medical doctor Giorgi Prodi, standardized and extended these concepts and gave rise to a new interdiscipline: biosemiotics. ${ }^{13,4}$

Semiotics is defined as the study of signs; and a sign is anything that is used in place of something else and, since a sign is always tied to a meaning, semiotics also includes the study of meanings. Likewise, the association between a sign and its meaning requires the presence of a third entity that establishes a relation between them through a set of conventions or codes, which is also a subject of study in semiotics. Finally, any semiotic system requires, in addition to the signmeaning-code triad, a fourth factor that is the decoder. 5,6

Based on the preceding, biosemiotics is defined as the study of signs, their meaning and interconnecting codes in living systems. At the most essential level of life, such as cells, signs are represented by the genotype; meanings, by the phenotype; codes, by the correspondence between deoxyribonucleic acid (DNA) and ribonucleic acid (RNA) nucleotides; and decoders, by the ribotype, i.e., the ribosome system responsible for DNA transcription and translation.

According to biosemiotics, as in the case of human language and mathematics, the rules governing semiosis in the biological world are universal and predetermined, so they should be discovered by decoders in an exploratory manner. Trifonov and other authors have stated that, in addition to the typical genetic code, there are at least twenty organic codes overlapping in the genome. Other authors, like Peirce and Taborsky, have even proposed the concept pansemiosis, which states that the semiosis process is inherent to the universe functioning in general, thus governing even the inorganic level. In brief, biosemiotics is based on the idea that all live beings constitute a semiotic system themselves, and semiosis is critical for the phenomenon of life because its essential unit is not a molecule in itself but its function as a sign (Hoffmeyer). ${ }^{5,7}$

\section{Biosemiotics: Levels of complexity}

Biosemiotics studies the natural world's language by exploring its varying levels of complexity: from cellular semiotics (cytosemiotics), where sign processes are chemical, electrical, mechanical, and thermal, to vegetative semiotics (phytosemiotics), animal semiotics (zoosemiotics), and finally, human semiotics (anthroposemiotics), at which level sign processes can even reach, through words, the representation of what is absent or even inexistent (fantasy). ${ }^{7,8}$ In this regard, from an evolutionary perspective, biosemiotics is divided into three major phases: an initial phase (primordial), where a rudimentary biological semiosis is established with the emergence of life; a second phase (hermeneutic), where beings with a nervous system emerge and a more complex semiosis with certain level of interpretation is established; and finally, an advanced phase (symbolic) of biological semiotics, where human beings appear and a language based on cultural codes is born. ${ }^{5}$

Therefore, in the biosemiotics universe, each complexity level uses its own particular sign system; so, the system used by biosemiotics at one level (e.g., tissues) is not necessarily the same used in the underlying level (e.g., cells) or in the overlying level (e.g., organs). ${ }^{1-4}$ However, it is worth noting that, since the semiotic activity that takes place in each level of biological complexity allows the semiotic activity to occur at the remaining levels, it is therefore inferred that there is necessarily a conversion system in place among the sign systems of the different levels that enables their dialog. The discovery of what would be the Rosetta Stone of biosemiotics, i.e., the stone inscribed in three languages that allowed Champollion to decipher, by comparison, Egyptian hieroglyphs, is one of the greatest challenges of this discipline because it would allow to decipher the equivalence (translation) between the different sign systems (languages) used at the different levels of the body's biological complexity. ${ }^{1,9}$

It is worth pointing out that, when a molecule (e.g., a cytokine) plays a sign role in a biosemiotic process, analogous to the dyadic model of the linguistic sing (word) proposed by Ferdinand de Saussure, such molecule-sign is considered to be made up of an equivalent of what would be the linguistic signifier (sound), which, in this case, 
would be the molecule-sign chemical structure (e.g., peptide) and, on the other side, an equivalent of what would be the meaning of a linguistic sign (concept), which, in this case, would be the potential action of the molecule-sign (e.g., proinflammatory action). Finally, the object of the real world represented by the linguistic sign (referent) would be, in this case, the actual effect of the molecule-sign's action (e.g., inflammation). ${ }^{1,10}$

The main difference between the biosemiotics of salutogenesis and pathogenesis and that of classical physiology and pathophysiology is that, whereas the latter are based on a structuralist perspective that believes in the existence of an organism as a sort of machine made up of parts (organs) that work in a harmonious manner (health) or in a dissonant manner (disease) in relation to the rest of the body, and that considers such structure as the one that develops processes, biosemiotics is based on an intermolecular dialogic perspective where cells, tissues, organs, and body are the product of such dialogs and that considers such structures as the result of semiotic processes. From this viewpoint, the ultimate reality would be made up of multiple intermolecular semiotic processes that, in turn, lead to growing complexity dialogs (among cells, tissues, etc.) and dialogs about the dialogs (metadialogs) that lead to biological sentences, including other subordinate biological sentences, thus leading to a flow of biological texts and hypertexts.

Therefore, in biosemiotics, a semiotic perspective (processes) takes precedence rather than a structuralist perspective (effects). In the latter, structures are illusions resulting from the lack of subtlety in human perception, which is not able to perceive, at first glance, the ultimate true structure, which is its brevity or, as in the words of Heraclitus, no physician ever examines the same heart twice because both its physiology and anatomy account for two rates, fast and slow, respectively, of the same process: the cardiac process. ${ }^{5,6,11}$

\section{The concept of the biosemiotic space}

At the organic level, dialogs within (intra-) and among (inter-) the different complexity levels, or biosemiotic connecting circuits, are expressed through a group of mediators of varying nature, such as hormones, neurotransmitters, second messengers, cytokines, etc., the true "words" of biosemiotics and whose type and amount vary depending on the nature of the dialogs established. Actually, the amount of information currently available about the dialogs (both normal and pathological) or crosstalks established between the different organs, e.g., between the liver and the lung or the kidney and the liver, which take place through the nervous, endocrine, and immune systems, is enough to develop a new discipline that furthers the study of these interrelation channels or biosemiotic spaces based on the interrelation of the respective disciplines, such as, in this case, between nephrology and pulmonology or between nephrology and hepatology, respectively. ${ }^{1,12,13}$

Therefore, as in the $19^{\text {th }}$ century Claude Bernard established a new idea of organism based on a novel perspective by describing it as the sum of two compartments: intracellular and extracellular spaces; ${ }^{9}$ nowadays, a new concept may be established from a novel perspective which considers that the organism is made up of a biological space and a biosemiotic space. From this point of view, the biological space would have several complexity levels or strata: intracellular, cellular, tissue, organic, and systemic. In this regard, the complexity level corresponding to organs and organ systems would be the one scientifically developed at present and implemented in the health care setting by the different medical specialties, such as nephrology, pulmonology, hepatology, etc.

The biosemiotic space would be that where the salutogenic and pathogenic dialogs among the components of the same biological complexity level (intrabiological) take place, such as among cells from a single organ, and/or among the components of different biological complexity levels (interbiological), e.g., the different body organs, whose study and development would lead to a new subspecialty focused on information flows between the different organs, a discipline that may be called biosemiotic medicine.

In addition, the development of these interface subspecialties, which together would contribute to shape biosemiotic medicine, far from promoting a greater fragmentation of medical knowledge, would encourage its reunification precisely by reconnecting the knowledge fields corresponding to the different organs by focusing on the biosemiotic space connecting them instead of on the organs resulting from such dialogs.

\section{Biosemiotic medicine: Towards a process- based medicine}

Based on the famous experiments about the physiology of vision, Maturana et al. 
demonstrated that the characteristics of perception were determined by the eye structure, not by the outside world object. The object becomes the stimulus necessary to trigger the perceptual phenomenon, and the reality of its existence makes visualization become a perception, not a hallucination (perception without object). However, perception is actually a false representation of the object, an explanatory argument developed by the observer as a result of structural determinism. Therefore, perception cannot be distinguished from illusion, because perception depends on the structural characteristics and internal correlations of the observer's nervous system rather than on the object's own characteristics. ${ }^{14}$

Based on the preceding, contemporary epistemology states that the ultimate reality is made up of a continuous flow (dialog) of Mendeléyev's periodic table elements, which become aggregated and disaggregated in an eternal evolution; and the human mind skillfully reduces such chaotic complexity to a comprehensible set of forms (symbols) and linguistic categories (signs). This demonstrates that there is no reality made up of forms and ideas (Platonism), but rather that it corresponds to human mind constructs (phenomena) developed based on its structural determinism grounded on the primordial magma of dancing elements (reversal of Platonism).

Based on the preceding, it should be noted that, between the symbolic forms and linguistic categories outlined by the human mind, which allow it to establish a representation (map) of reality, there is always a blind spot (foggy interstice) where there is no representation and, therefore, no interpretation. ${ }^{15,16}$ Such phenomenon, extrapolated to the field of medicine, demonstrates that the disease model, based on the anatomical-physiological (structural) perspective, does not take the biosemiotic aspect of pathogenesis into consideration, because, actually, disease is the result (effect) of a pathological dialog (biosemiotic space) established among body organs (biological space) in an early manner, i.e., a pathological dialog prior to the onset of structural damage. In this way, the involvement of the biosemiotic space precedes the involvement of the biological space because, actually, the latter is the result of the former; in other words, the biosemiotic process leads to a different process with a lower rate and a greater density that is the biological process.
This means that biosemiotic medicine, i.e., not based on diseased organs (biological space) but on the preceding pathological dialogs (biosemiotic space), would allow to go from the current effectbased model (diseased organ-based medicine) to a process-based model (biosemiotic medicine). The latter, which is based on processes, may be able to detect the presence of pathological biosemiotics (pathogenesis) in an early manner (before the onset of structural damage) and ensure its recomposition and redirection towards normal biosemiotics (salutogenesis). In order to establish such medicine model (biosemiotic medicine) in the future, it is critical to develop interface specialties as well as new contributions from biosemiotics and, above all, endosemiotics.

Therefore, just like the anatomical model of body compartments defined by Claude Bernard $\left(19^{\text {th }}\right.$ century) allowed for a better interpretation and treatment of electrolyte imbalances, which was not possible with the classical anatomical model developed by Vesalius ( $16^{\text {th }}$ century), the biosemiotic medicine model would be the biosemiotic space model, and would focus on the semiosis established within and among the different body levels. ${ }^{8,17}$ Such new model would encourage the development of a deeper understanding of how salutogenic and pathogenic circuits function, and would give rise to a medicine that would promote the early diagnosis and management of disease processes (biosemiotic medicine) and would attempt to neutralize such processes by working at the biosemiotic space level before they become patent in the biological space (conventional disease).

\section{CONCLUSION}

The development of subspecialties focused on the study of the biosemiotic spaces that exist at the multiple body levels may give rise to a new process-based medicine or biosemiotic medicine, with the subsequent advantage of an early disease diagnosis and management.

\section{Acknowledgments}

I would like to thank Henry GonzálezTorres, MSc, for his valuable collaboration reviewing this article.

\section{REFERENCES}

1. Barbieri M. Introduction to biosemiotics: The new biological synthesis. Dordrecht: Springer; 2007.

2. Brentari C. Jakob von Uexküll: The discovery of the Umwelt between biosemiotics and theoretical biology. Dordrecht: Springer; 2015. 
3. Favareau D. Essential readings in biosemiotics. Dordrecht: Springer; 2010.

4. Romanini V, Fernández E (eds.). Peirce and biosemiotics: A guess at the riddle of life. Dordrecht: Springer; 2014.

5. Barbieri M. Biosemiotics: a new understanding of life. Naturwissenschaften. 2008; 95(7):577-99.

6. Adiguzel Y. Biophysical and biological perspective in biosemiotics. Prog Biophys Mol Biol. 2016; 121(3):245-54.

7. Brier S. Can biosemiotics be a "science" if its purpose is to be a bridge between the natural, social and human sciences? Prog Biophys Mol Biol. 2015; 119(3):576-87.

8. Sharov AA. Evolutionary biosemiotics and multilevel construction networks. Biosemiotics. 2016; 9(3):399-416.

9. Lambert T. Diccionario de los dioses y mitos del Antiguo Egipto. Barcelona: Océano; 2003.

10. Saussure F. Curso de lingüística general. Buenos Aires: Losada; 2009.

11. Kull K. Semiosis stems from logical incompatibility in organic nature: Why biophysics does not see meaning, while biosemiotics does. Prog Biophys Mol Biol. 2015; 119(3):616-21.
12. Domenech P, Perez T, Saldarini A, Uad P, et al. Kidneylung pathophysiological crosstalk: its characteristics and importance. Int Urol Nephrol. 2017; 49(7):1211-5.

13. Capalbo O, Giuliani S, Ferrero-Fernández A, Casciato $\mathrm{P}$, et al. Kidney-liver pathophysiological crosstalk: its characteristics and importance. Int Urol Nephrol. 2019; 51(12):2203-7.

14. Maturana-Romesin H, Varela GF. Elárbol del conocimiento: Las bases biológicas del entendimiento humano. Santiago de Chile: Lumen; 2003.

15. Garagalza Arrizabalaga L. El sentido de la hermenéutica: La articulación simbólica del mundo. Barcelona: Anthropos; 2014.

16. Musso CG. Epistemología de la introspección: la clave de la investigación científica. Arch Argent Pediatr. 2019; 117(6):357-9.

17. Kosoy M, Kosoy R. Complexity and biosemiotics in evolutionary ecology of zoonotic infectious agents. Evol Appl. 2017; 11(4):394-403. 